\title{
Adaptasi Ikom Radio: Dari Analog menjadi Digital di Masa Pandemi
}

\section{Covid-19}

\author{
Aromah Udaningrum Kusumadewi \\ Program Studi Ilmu Komunikasi, Universitas Muhammadiyah Yogyakarta, Indonesia \\ aromah.u.isip19@mail.umy.ac.id \\ Meri Noviyanti \\ Program Studi Ilmu Komunikasi, Universitas Muhammadiyah Yogyakarta, Indonesia \\ meri.n.isip19@mail.umy.ac.id \\ Sefila Ananda Talia \\ Program Studi Ilmu Komunikasi, Universitas Muhammadiyah Yogyakarta, Indonesia \\ sefila.ananda.isip.19@mail.umy.ac.id \\ Diserahkan: 14 Juni 2021; Direvisi: 1 Juli 2021; Diterima: 9 Juli 2021
}

\begin{abstract}
Ikom Radio 107.7 fm UMY is a student community radio located within the University of Muhammadiyah Yogyakarta (UMY) campus. The name of IKOM Radio corresponds to the name of the department | faculty of the University of Muhammadiyah Yogyakarta, namely Communication Studies (IKOM). Radio which initially broadcast using the community frequency 107.7 FM until now there has been no change in frequency. Established as a radio broadcasting learning (Broadcast) since the analog era to the current digital media era. Through this streaming, listeners can join by requesting songs through the available chatbox on the website or application. And for information about streaming and various other interesting radio icons, you can see the IKOM radio instagram account. With the current condition of the pandemic, the radio icon is still broadcasting (streaming) even though the system is no longer on air but tapping. From the impact of this pandemic, it is difficult for radio ikom to coordinate, to overcome this ikom radio makes a policy to take advantage of the zoom platform. Keywords: Covid-19; Analog Radio; Streaming
\end{abstract}

\section{Abstrak}

Ikom Radio 107.7 fm UMY merupakan radio komunitas mahasiswa yang ada di dalam lingkungan Kampus Universitas Muhammadiyah Yogyakarta (UMY). Nama IKOM Radio sesuai dengan nama jurusan | fakultas Universitas Muhammadiyah Yogyakarta, yaitu Ilmu Komunikasi (IKOM). Radio yang pada awalnya mengudara menggunakan frekuensi komunitas 107.7 FM hingga sekarang tidak ada perubahan frekuensi. Didirikan sebagai pembelajaran penyiaran (Broadcast) radio sejak era analog sampai era digital media sekarang. Melalui streaming ini, pendengar dapat bergabung dengan me-request lagu melalui chatbox yang tersedia yg ada di website maupun aplikasinya. Dan untuk informasi mengenai streaming dan berbagai informasi tentang ikom radio menarik lainnya, bisa di lihat di akun instragramnya IKOM radio. Dengan kondisi saat ini masih pandemi ikom radio masih tetap melalukan siaran (streaming) walaupun sistemnya bukan lagi on air melainkan tapping. Dari dampak pandemi ini menyulitkan ikom radio untuk berkoordinasi, untuk mengatasi hal ini ikom radio membuat kebijakan untuk memanfaatkan platfrom zoom.

Kata Kunci: Covid-19; Radio Analog; Streaming 


\section{PENDAHULUAN}

Perkembangan Covid-19 di Indonesia terdeteksi pada tanggal 2 Maret 2020, dan untuk pertama kalinya pada tanggal 11 Maret 2020 warga negara Indonesia meninggal akibat covid-19. Dalam waktu satu bulan covid-19 tersebar di Indonesia, angka kasus pengidap covid-19 mencapai puluhan ribu kasus yang tetap terus bertambah hingga saat ini sampai dengan ditemukannya vaksin (Kompas, 2020). Dampak dari covid19 sangat memengaruhi berbagai sektor yaitu kesehatan, pendidikan, ekonomi, sosial, dan budaya. Dampak covid- 19 dari segi perekonomian dunia sangat dahsyat, di Indonesia sendiri banyak perusahaan yang menutup bisnisnya karena tidak sanggup menanggung biaya operasioanal perusahaan. Terdapat pula perusahaan yang tetap bertahan namun dengan melakukan pengurangan tenaga kerja.

Berdasarkan data yang ditemui peneliti bahwa total tenaga kerja yang telah terkena PHK (Pemutusan Hubungan Kerja) pada bulan April tahun 2020 mencapai 1,65 juta lebih di Indonesia (Detikfinance, 2020). Pemutusan hubungan kerja yang dilakukan perusahaan ini sebagai upaya untuk mengurangi biaya operasional perusahaan. Salah satu sebab adanya pemutusan hubungan kerja adalah pembatasan aktivitas sosial masyarakat di luar rumah. Pada masa pandemi covid-19 mengharuskan masyarakat untuk mengurangi aktivitas di luar rumah sebagai pencegahan terpapar dengan covid-19, sehingga hal hal tersebut memengaruhi pendapatan perusahaan. Ditambah dengan adanya penerapan Pembatasan Sosial Berskala Besar (PSBB) membuat masyarakat tidak dapat menjalani aktivitas seperti biasa dengan anjuran kebijakan pemerintah work from home (WFH) dan school from home dengan begitu semua aktivitas hanya bisa dilakukan di rumah. Dengan adanya dampak covid-19 ini perusahaan bisnis mengharuskan mengubah pola penerapan strategi yang digunakan agar dapat tetap bertahan.

Salah satu bisnis dalam media yang harus tetap berjalan adalah radio untuk memberikan informasi dengan menyampaikan pesan secara cepat dan serentak. Radio menggunakan teknologi modulasi dan radiasi gelombang elektromagnetik sebagai pengirim sinyal (Rahanatha, 2008). Radio sampai saat ini masih memiliki daya tarik tersendiri bagi pendengarnya karena difungsikan sebagai latar belakang, hal tersebut dapat disadari dari banyak masyarakat dan kalangan yang memanfaatkan radio sebagai pengiring dan teman pada saat sedang melakukan kegiatan atau pekerjaan (Putri, 2020).

Radio yaitu siaran (pengiriman) suara atau bunyi melalui udara.Radio merupakan media komunikasi massa konvensional yang memiliki pendengar diseluruh Indonesia, yang didirikan untuk memberikan sejumlah informasi penting tentang peristiwa yang terjadi disekeliling kita baik dalam bentuk hard news maupun soft news. Sejak zaman kemerdekaan, radio digunakan untuk menyebarluaskan informasi kemerdekaan dan pesan- pesan perjuangan saat itu. Setelah Indonesia mulai nyaman dengan kondisi setelah kemerdekaan, maka fungsi radio cenderung menjadi media hiburan (Choirunnissa, 2021).

Radio sering disebut-sebut sebagai media buta karena hanya menampilkan audio tanpa visual. Akan tetapi, radio dalam menjalankan perannya sebagai sarana komunikasi masal tetap dipercaya oleh khayalak. Pentingnya peran media radio dalam penyebaran penyampaian informasi publik dan radio tidak bisa terlepas dari fungsi-fungsi tersebut karena radio termasuk dalam media pers. Rudianto mengutip Haddow and Kims (2008) berpendapat bahwa kemampuan untuk mengkomunikasikan pesanpesan tentang bencana kepada publik, pemerintah, media dan pemuka pendapat dapat mengurangi resiko, menyelamatkan kehidupan dan dampak dari bencana.

Untuk membantu masyarakat mendapatkan kabar yang benar, Komisi Penyiaran Indonesia (KPI) mengeluarkan edaran dengan nomor 123/K/KPI/31.2/03/2020. Isinya, kepada media televisi dan radio membantu memberikan info seputar Covid-19 tetap profesional, proporsional, dan tidak berlebihan (Koko, 2020). Masyarakat, saat ini, mengikuti dan membutuhkan kabar perkembangan, penanggulangan, pengetahuan seputar Covid-19 dengan cepat dan benar sehingga penyebaran informasi secara berkala sangat dibutuhkan. Ini berarti meyakinkan bahwa media radio menjadi salah satu media massa yang efektif dalam penyebaran pemberitaan yang mengenai virus Corona ini karena di dalam aturannya media 
massa sebelum menyiarkan informasi harus melalui proses klarifikasi yang sesuai dengan Kode Etik Jurnalistik (KEJ). Radio siaran termasuk ke dalam kategori media massa elektronik yang dapat menstimuli khalayak secara luas dalam waktu bersamaan. Ketika suara terdengar dari pesawat radio, saat itu juga berusaha menvisualisasikan makna dari suara tersebut. Efek suara dan dukungan musik yang tepat membawa radio siaran menjadi alat komunikasi dalam kehidupan masyarakat yang dapat diperhitungkan dampaknya (Widiyasari et al., 2015).

Penelitian ini adalah untuk mengetahui adaptasi Ikom Radio dari analog menjadi digital di masa pandemi covid-19, termasuk tentang protokol kesehatan yang ditegakan selama penyiaran. Penelitian terdahulu tentang radio yang dilakukan oleh Areta Putri di Kantor Radio Suara Surabaya yang beralamatkan jalan Wonokitri Besar No. 40 C, Pakis, Kecamatan Sawahan, Kota Surabaya, Provinsi Jawa Timur, Kode Pos 60256. Subjek penelitian yang diwawancarai oleh peneliti karena berfokus pada implementasi komunikasi pemasaran dalam mendapatkan iklan pada masa pandemi Covid-19, maka peneliti memilih Manajer Marketing Promotion sebagai informan dan Manajer Account Executive.

Penelitian terkait lainnya yaitu "Seleksi Penyiar Radio Tanjung Puri Menggunakan Metode Weighted Product” oleh Ridhanty Azmi Syafitri, Ruliah S. Pada penelitian sebelumnya menggunakan metode WP terdapat 6 kriteria dan 18 alternatif. Penelitian sekarang memiliki perbedaan diantaranya metode yang digunakan lebih bersifat kompleks yakni metode ELECTRE dan menggunakan 5 alternatif dan 4 kriteria yang dihasilkan dari melakukan wawancara langsung dengan pihak manjemen radio (Damanik et al., 2017).

Berbeda dengan penelitian yang dilakukan oleh Faridensyah (2019) dengan judul "Strategi Promosi Media Massa Melalui Event (Studi Kasus Event Jazz Traffic Festival Suara Surabaya)”. Penelitian tersebut menghasilkan dampak dari adanya Jazz Traffic Festival yaitu meningkatkan brand image radio Suara Surabaya. Dengan begitu dapat memudahkan untuk mendapatkan sponsor dan memperkenalkan radio Suara Surabaya kepada kalangan remaja yang menjadi target pendengar radio Suara Surabaya.

Referensi dari penelitian lainnya yaitu penelitian oleh Andika (2018) dengan judul "Strategi Komunikasi Pemasaran Radio Suara Surabaya Dalam Mempertahankan Eksistensi”. Dengan hasil penelitian tersebut yaitu dengan mempertahankan eksistensi radio, strategi komunikasi pemasaran yang dilakukan oleh tim promosi dan Manajer Marketing radio Suara Surabaya yaitu dengan pengiklanan, event, dan kerja sama dengan media partner lain. Selanjutnya terdapat penelitian tentang komunikasi pemasaran radio Suara Surabaya oleh Kastaya, (2014) dengan judul "Strategi Komunikasi Pemasaran Radio Lokal: Studi Kasus Strategi Komunikasi Pemasaran Radio Suara Surabaya Periode 2010-2014” (Putri, 2020).

\section{KAJIAN PUSTAKA}

Corona virus merupakan virus jenis baru yang kini telah menggemparkan masyarakat dunia (Mona, 2020). Masalahnya virus ini telah berhasil menginfeksi ribuan juta masyarakat global dalam waktu yang sangat singkat (Li et al., 2020). Bahkan manusia tanpa menunjukkan gejala terinfeksi Corona virus dapat pula menyebarkan kepada manusia lainnya (Kumar \& Dwivedi, 2020). Mengantisipasi peningkatan penyebaran dan jumlah infeksi, masyarakat dihimbau untuk melakukan pola hidup sehat baru sesuai protokol kesehatan semasa pandemi Corona virus. Salah Wellness and Healthy Magazine, 2(2), Agustus 2020, - 238 Faura Dea Ayu Pinasti satu bentuk protokol tersebut adalah menjaga kebersihan dan tidak melakukan kontak langsung dengan pasien positif Corona virus (Izzaty, 2020). Kemudian, menggunakan masker pelindung wajah saat bepergian atau diluar rumah (Howard et al., 2020). Selanjutnya, menjaga kebersihan dengan mencuci tangan atau menggunakan handsanitizer (Lee et al., 2020). Terakhir adalah penerapan social distancing dengan menjaga jarak sejauh 1 meter dan menutup mulut saat batuk atau bersin menggunakan lengan(Hafeez et al., 2020).(Pinasti, 2020) 
Penanganan informasi publik pandemi Covid-19 adalah bagian dari komunikasi bencana (krisis) dan komunikasi kesehatan. William J. Paisley dalam tulisannya Public Communication Campaigns: The American Experience" dalam Rice \& Atkin (2001), menjelaskan bahwa penyampaian informasi kesehatan publik dianggap program layanan publik, jika didukung publik dan pembuat kebijakan (pemerintah). Robert A. Logan menulis mengenai Health Campaign Research dalam Bucchi \& Trench (2008), menjelaskan komunikasi publik mengenai kesehatan bersifat informatif dan persuasif. Tujuannya untuk mengubah pengetahuan, kesadaran, dan sikap publik mengenai cara mengatasi suatu penyakit atau kesehatan.

Komunikasi publik di bidang kesehatan berupaya meningkatkan:(1) Kesadaran dan pengetahuan (Kognitif) publik; (2) Sikap (Afektif, perasaan, motivasi); (3) Kecenderungan perilaku (Konatif), tentang penyakit, ancaman, masalah dan solusi kesehatan. Kampanye kesehatan adalah suatu intervensi, strategi komunikasi konstruktif yang dirancang untuk mempengaruhi dan meningkatkan kesehatan masyarakat. Informasi kesehatan publik berisi informasi kehidupan, kematian, harapan, ketakutan, kesehatan, kemajuan, kegagalan, fakta, spekulasi dan resiko penyakit (Levi, 2000). Dasar kebijakan pemerintah dalam penanganan informasi Pandemi Covid-19 adalah Protokol Komunikasi Publik Penanganan Covid19 (Kantor Staf Presiden, 2020), yang menjadi petunjuk teknis Pemerintah Pusat dan Daerah dalam penanganan informasi Covid-19. Protokol ini diadopsi dari protokol WHO. Ada Kampanye kesehatan adalah suatu intervensi, strategi komunikasi konstruktif yang dirancang untuk mempengaruhi dan meningkatkan kesehatan masyarakat. Informasi kesehatan publik berisi informasi kehidupan, kematian, harapan, ketakutan, kesehatan, kemajuan, kegagalan, fakta, spekulasi dan resiko penyakit (Levi, 2000).

Dasar kebijakan pemerintah dalam penanganan informasi Pandemi Covid-19 adalah Protokol Komunikasi Publik Penanganan Covid-19 (Kantor Staf Presiden, 2020), yang menjadi petunjuk teknis Pemerintah Pusat dan Daerah dalam penanganan informasi Covid- 19. Protokol ini diadopsi dari protokol WHO. Ada empat pilar komunikasi publik pemerintah terkait Covid-19: (1) Himbauan masyarakat tetap tenang dan waspada; (2) Koordinasi instansi terkait; (3) Akses informasi ke media; (4) Pengarusutamaan gerakan "Cuci Tangan Dengan Sabun". Instruksi Presiden ingin menunjukkan bahwa Pemerintah serius, siap dan mampu untuk menangani wabah. Informasi disampaikan secara komprehensif dan berkala mengenai apa yang telah, sedang dan akan dilakukan pemerintah (Fadhal, 2005).

Undang-Undang No. 32 Tahun 2002 mengatur lembaga penyiaran komunitas dalam Pasal 21 hingga Pasal 24. Keberadaan lembaga penyiaran komunitas ini lebih jauh diatur dalam PP No. 51 tahun 2005 untuk lembaga penyiaran komunitas. Radio komunitas dimiliki, dikelola, diperuntukkan, diinisiatifkan, dan didirikan oleh sebuah komunitas sehingga sering disebut sebagai radio sosial, radio pendidikan, atau radio alternatif. Dengan demikian, radio komunitas dapat dijadikan sebagai wahana komunikasi milik masyarakat yang potensial untuk melayani kepentingan komunitasnya sendiri. Dengan kata lain, fungsi dan potensi radio komunitas sangat stategis untuk memercepat perubahan sosial di kalangan masyarakat yang mendirikan dan mengelola radio komunitas (P. Rianto, Rahayu, 2014).

Sebuah organisasi haruslah mempunyai suatu aturan yang membatasi semuanya untuk kebaikan kita bersama (organisasi), apalagi untuk sebuah media massa elektronik seperti radio ini diperlukan aturanaturan yang tegas dan detail agar semua crew mematuhinya. Setiap bidang pekerjaan pasti mempunyai hambatan atau kesulitan tersendiri yang harus dihadapi oleh orang yang berada pada bidang tersebut, banyak hambatan yang bisa kita alami dari bidang tersebut, baik hambatan internal maupun eksternal. Dengan adanya hambatan-hambatan yang kita alami dalam suatu pekerjaan, maka hambatan itu bisa berakibat baik dan buruk bagi kita ataupun perusahaan.

Mungkin anda sudah tidak asing lagi dengan keberadaan radio analog. Radio jenis analog sangat booming di era 80-an hingga 90-an. Fungsinya pun beragam, mulai dari sarana komunikasi untuk 
perusahaan besar seperti perusahaan pertambangan, komunikasi antar masyarakat hingga sebagai sarana hiburan. Pada dasarnya, radio analog menggunakan gelombang elektromagnetik dalam mengirimkan sinyal dan memiliki sifat variabel yang berurutan (Adi Muhammad Ramadhan, 2018).

Analog merupakan sistem penggelolaan sinyal yang datanya dapat diolah secara kontinyu atau bertahap. Kata lain dari sistem analog mempunyai "range "dalam pengelola data dan sinyal. Dengan adanya Kondisi saat ini di penyiaran analog, masing-masing lembaga penyiaran memiliki infrastruktur penyiarannya sendiri-sendiri seperti menara pemancar, antena, dan sebagainya. Akibatnya, biaya pemeliharaan yang relatif mahal, pemakaian daya listrik yang besar, serta pemanfaatan lahan yang lebih boros. Di sisi penerimaan siaran pun terjadi masalah karena masyarakat mendapat kualitas penerimaan siaran yang tidak merata meski berada dalam wilayah layanan yang sama. Penerapan teknologi penyiaran digital memberikan efisiensi penggunaan spektrum frekuensi yang lebih baik sehingga dapat memenuhi kebutuhan penyediaan program siaran yang berlipat kali lebih banyak dibandingkan penyiaran analog (Gultom, 2015).

Bagian depan analog SDR. Untuk berpartisipasi dalam penghematan daya rata-rata dan mencapai tujuan ini, ujung depan analog harus menyesuaikan kinerjanya (dan konsumsi daya) dengan persyaratan tautan yang berubah (pengguna) dan kondisi (saluran) dan secara rata-rata. Konsumsi daya jelas perlu dibatasi dan bahkan diminimalkan secara dinamis untuk membawa masa pakai baterai ke tingkat yang dapat diterima. Namun, fleksibilitas datang dengan mengorbankan kerumitan dan daya ekstra, dan ujung depan di setiap mode tertentu tidak boleh melebihi (terlalu banyak) konsumsi daya dari satu radio mode tunggal. Blok penyusun RF dan baseband harus dapat dikonfigurasi ulang dalam pertunjukan (bandwidth saluran dan frekuensi pusat, kebisingan, penguatan, linieritas, dan lain-lain).

Software Radio (SR) adalah radio canggih yang menggunakan perangkat lunak untuk membuat perangkat komunikasi berkinerja tinggi dan fleksibel yang melakukan sebagian besar tugas pemrosesan sinyal secara digital yang biasanya ditangani sirkuit analog. Ini menawarkan keuntungan dengan menempatkan banyak fitur yang secara tradisional tidak fleksibel dalam modul yang karakteristiknya dapat diubah saat radio berjalan (Wolf, 2005). Misalnya, daripada merancang satu radio untuk menerima hanya frekuensi pembawa tertentu, bandwidth, dan modulasi seperti yang didefinisikan oleh standar nirkabel, para insinyur dapat memprogram transceiver digital yang sangat fleksibel untuk memberikan kemampuan penerimaan pada berbagai frekuensi saat radio beroperasi.

Satu-satunya komponen analog adalah antena yang dapat dikonfigurasi ulang dan LNA jangkauan dinamis tinggi dengan Kontrol Penguatan Otomatis (AGC) bawaan. Konversi analog-ke-digital dilakukan segera di RF untuk menguraikan sinyal secara digital pada antarmuka udara yang fleksibel. Operasi penurunan konversi dan pemfilteran dilakukan oleh DSP pita dasar yang dapat diprogram ulang. DSP memproses sinyal digital sesuai dengan lingkungan nirkabel. Contoh yang baik dari transceiver SR yang ideal adalah prototipe yang dirancang oleh aplikasi UK Defense Agency for High Frequency (HF) (Davies, 2000). Komunikasi milier mungkin sangat diuntungkan dengan menggunakan transceiver SR dan oleh karena itu mendigitalkan dan mendemodulasi seluruh bandwidth yang diinginkan. Dengan mengonversi dan memfilter setiap saluran dalam pita secara digital, satu ADC memungkinkan penerimaan secara simultan dari apa pun yang ada di udara pada saat itu juga. Integrasi penuh masih dimungkinkan karena rentang frekuensi yang diinginkan, dalam hal ini dari 3 hingga $30 \mathrm{MHz}$, memerlukan konverter 12 bit, $75 \mathrm{MHz} \mathrm{A} / \mathrm{D}$, yang merupakan teknologi canggih. ADC ditempatkan di awal jalur sinyal, kemudian menggunakan DSP untuk pemilihan saluran dan demodulasi. Namun, Low-Pass Filter (LPF) diperlukan sebelum konversi ke domain digital untuk menghindari aliasing dan membatasi resolusi ADC. Manfaat potensial dari arsitektur ini termasuk pengurangan kompleksitas, jumlah komponen yang lebih rendah, penerimaan beberapa saluran secara bersamaan, konfigurasi ulang, dan beberapa keuntungan kinerja (Vito Giannini, Jan Craninckx, 1377). 
Semakin berkembangnya teknologi, mau tidak mau juga membuat komunikasi radio berkembang ke ranah digital. Kehadiran sistem radio digital, khususnya di Indonesia seolah memberikan jawaban atas padatnya penggunaan radio analog khususnya untuk modulasi FM. Sistem radio digital dalam hal penyaluran sinyalnya dapat mengubah informasi analog menjadi angka-angka biner yang nilainya berubah-ubah sesuai besaran sinyal analog yang masuk melalui pemancar radio digital. Proses inilah yang dinamakan decode.

Digitalisasi penyiaran memang dimaksudkan menciptakan efisiensi pengelolaan infrastrukur penyiaran, tidak seperti yang selama ini terjadi pada pengelolaan penyiaran dengan teknologi analog. Penggunaan frekuensi penyiaran dengan teknologi digital yang lebih hemat dari pada analog, tentunya akan tersedia sisa frekuensi (digital deviden) sebagai dampak migrasi analog ke digital. Mengingat spektrum frekuensi radio merupakan sumber daya terbatas, maka digital deviden wajib dikuasai oleh negara dan digunakan untuk kepentingan penyelenggaraan penyiaran sesuai dengan arah kebijakan sistem Penyiaran nasional. Besarnya digital deviden yang akan didapatkan, banyak tergantung pada besaran penggunaan frekuensi digital di setiap zona wilayah siar (Asri, 2020).

Pada era global sekarang ini persaingan di industri media terjadi sangat ketat ketatnya persaingan media merupakan sebuah tantangan tersendiri bagi para pengelola media. Keberhasilan pengelola dalam menyusun strategi bisnis memberikan peluang statsion radio bisa bertahan atau tidak dari persaingan ini. Radio adalah salah satu jenis media massa elektronik tertua yang sampai saat ini masih tetap menjadi pilihan karena mengandung unsur musik dan kata-kata, serta memiliki jangkauan paling luas karena kemampuannya menembus jarak dan waktu adalah media radio siaran. Sifat radio yang personal dan portable adalah keunggulan media ini untuk menjadi "teman" yang selalu siap menemani kapan pun dan dimana pun pendengarnya berada.Sebagaimana media massa yang lain radio menyampaikan informasi pesan budaya untuk mempengaruhi serta merefleksikan budaya yang hidup dalam masyarakat tersebut. Media penyiaran radio merupakan system tersendiri yang merupakan bagian dari sistem kemasyarakat sama seperti system ekonomi, politik, dan lain sebagainya (dadang sugiana, 2019).

Semua stasiun pada awalnya dialokasikan pada frekuensi AM dan FM tetapi pada pertengahan tahun delapan puluhan stasiun komersial didorong untuk 'membagi' transmisi, menawarkan layanan program yang berbeda pada setiap frekuensinya. Banyak yang memilih pop di FM dan oldies dengan lebih banyak pidato dan informasi tentang AM. Meskipun jumlah stasiun radio meningkat pesat, jumlah orang yang mendengarkan radio - nasional, regional atau lokal - masih tetap sama, yaitu sekitar 45 juta orang. Sembilan dari sepuluh orang di Inggris adalah pendengar radio biasa (Chantler \& Stewart, 2009).

Pada tahun 2000-an, jumlah masyarakat Indonesia yang mendengarkan radio menunjukkan penurunan, tidak sebanyak pada masa lalu. Pendengar radio mulai beralih ke media-media yang lebih modern dan interaktif seperti televisi dan internet. Dalam kondisi seperti ini, pengelola radio melakukan berbagai strategi guna menarik dan memertahankan minat pendengar, khususnya di kalangan generasi muda. Integrasi dengan teknologi, penajaman segmen, dan perluasan usaha berupa aktivitas off-air menjadi jurus utama dalam menjaga loyalitas pendengar, khususnya bagi radio komersial. Kenyataan lain bahwa pendengar radio di Indonesia saat ini mayoritas telah memiliki handphone yang sebagian memiliki fitur mendengarkan radio. Bahkan, mereka juga bisa koneksi ke internet. Oleh karena itu, pengelola radio mengenalkan konvergensi media sebagai cara mengakses radio, seperti penggunaan teknik siaran streaming dan podcasting meskipun secara umum radio transistor masih merupakan pilihan utama publik pendengar radio. 


\section{METODE PENELITIAN}

Metode penelitian yang dipilih dalam penelitian ini adalah dengan memakai metode studi kasus. Metode studi kasus dipilih dalam penelitian ini, dilatarbelakangi bahwa penelitian ini memiliki tujuan untuk menguji pertanyaan dan masalah penelitian. Pengujian terhadap pertanyaan dan masalah penelitian yang tidak dapat dipisahkan antara fenomena serta konteks di mana fenomena tersebut terjadi.

Pemilihan metode penelitian studi kasus dalam penelitian ini dilakukan dengan mempertimbangkan beberapa hal. Pertama, fokus penelitian adalah untuk menjawab pertanyaan "bagaimana" dan "mengapa". Kedua, dalam penelitian studi kasus, peneliti tidak boleh melakukan manipulasi terhadap perilaku obyek yang diteliti yang terlibat didalam penelitian. Ketiga, peneliti ingin menutupi kondisi kontekstual dilatarbelakangi karene peneliti mempunyai keyakinan bahwa hal itu relevan dengan yang diteliti. Terakhir, adanya batas tidak jelas antara fenomena dan konteks yang diteliti (Yin, 2008). Dalam pelaksanaan penelitian ini, studi kasus dilaksanakan dengan meneliti Proses produksi Ikom Radio dari Aanalog Menjadi Digital di Masa Pandemi Covid-19.

Metode pengumpulan data dalam pelaksanaan penelitian studi kasus dalam penelitian ini dilakukan dengan berbagai cara. Pertama, adalah pengumpulan data dilakukan dengan observasi partisipan. Kekuatan pengumpulan data dengan observasi partisipan berakar pada observasi proses aktual "di lapangan”. Peneliti dapat mengamati rutinitas kerja yang sebenarnya, selama observasi, merekam proses pengambilan keputusan, konflik, negosiasi, dan kompromi, yang kesemuanya merupakan bagian dari proses produksi di berbagai tingkatan (Given, 2008). Sayangnya metode pengumpulan data ini menjadi lebih sulit dilakukan di masa pandemi Covid-19, karena adanya protokol kesehatan. Jika memungkinkan, metode ini akan dilakukan dengan melakukan observasi pada Radio Komunitas Ikom Radio.

Kedua, pengumpulan data dilakukan dengan wawancara mendalam. Kekuatan utama wawancara sebagai metode adalah kemampuannya untuk menjangkau berbagai perspektif tentang topik tertentu. Berbagai wawancara dapat digunakan untuk menambah informasi dan memperluas sudut pandang dalam penelitian tentang Produksi Ikom Radio dari Analog Menjadi Digital di Masa Pandemi Covid-19 yang sedang dilakukan ini. Semua wawancara dapat digunakan sebagai perangkat heuristik, karena informasi baru mengarah pada perspektif dan pertanyaan baru untuk subjek selanjutnya (Given, 2008) Dalam penelitian ini, wawancara akan dilakukan kepada Ridho Awan Kusuma yang menjabat sebagai Direktur Ikom Radio di Universitas Muhammadiyah Yogyakarta.

Ketiga adalah dengan studi dokumen dan arsip. Dokumen, bisa berupa surat, memorandum, agenda, dokumen administrasi, artikel surat kabar, atau dokumen apapun yang erkaitan dengan penyelidikan. Triangulasi bukti dengan dokumen berfungsi untuk menguatkan bukti dari sumber lain. Dokumen juga dapat dipakai guna menarik kesimpulan pada suatu peristiwa, mengarah pada petunjuk palsu jika peneliti tidak berpengalaman. Dokumen dapat berbentuk arsip, seperti catatan layanan, catatan organisasi, daftar nama, hasil survey (Yin, 2008). Pada penelitian ini, arsip yang diteliti adalah dokumen yang bersumbar dan atau berkaitan dengan agenda.

Setelah pengumpulan data dilakukan dan data terkumpul, selanjutnya dilakukan proses reduksi data dengan melakukanpemilihan data yang bisa digunakan dan data diabaikan. Data yang terpilih selanjutnya dianalisis dengan menggunakan analisis data studi kasus yang dilakukan dengan melakukan kategori data. Setelah ada kategori data, dilanjutkan dengan mengatur data dengan empat cara, yaitu pencocokan pola, membangun penjelasan, menemukan logika model, dan melakukan analisis timeseries (Yin, 2008).

Teknik tambahan dilakukan ketika menggunakan beberapa kasus, disebut sebagai sintesis untuk mencari pengulangan dalam kasus. Produk akhirnya adalah narasi yang menceritakan tentang kasus, yang memungkinkan pembaca sepenuhnya menjadi paham pada pada kasus yang terjadi (Prihatsanti et al., 2018). 


\section{HASIL DAN PEMBAHASAN}

HASIL

Berdasarkan observasi yang dilakukan pada Studio Ikom Radio Universitas Muhammadiyah Yogyakarta pada 6 April 2021, Studio Ikom Radio berada di Gedung E1 lantai 2, disamping secretariat Komahi UMY. Sekaligus melakukan proses rekaman wawancara oleh Direktur Ikom radio Ridho Awan Kusuma yang bertempat di kampus Universitas Muhammadiyah Yogyakarta (UMY) ruangan Ikom Radio, dan ruangan Yang cukup besar untuk siaran Ikom Radio dan di fasilitasi ruangan full AC dan peralatan lengkap Ikom Radio dan mahasiswa nyaman untuk siaran.

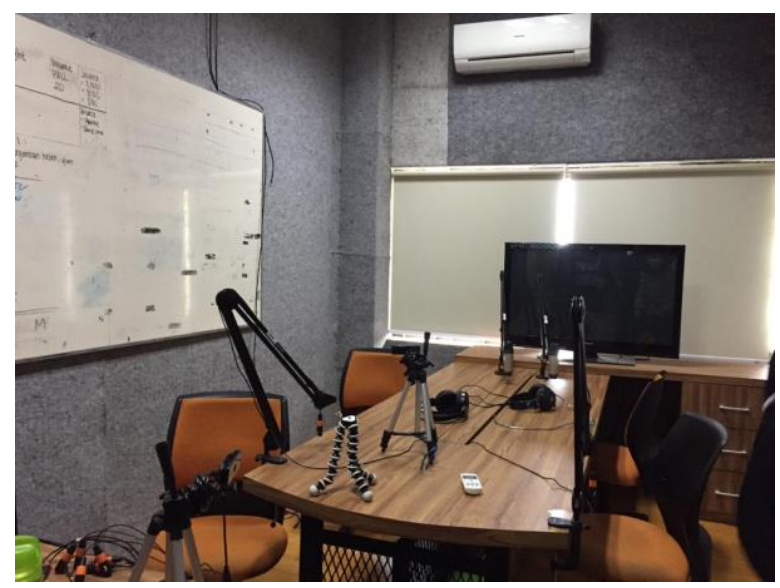

Gambar 1. Ruang Siaran Radio

Selain wawancara langsung kepada Ridho Awan Kusuma, kami juga melakukan wawancara melalui via WhatsApp kepada Audrey Vania Zachrani Kinasih. Kapan awal mula Ikom Radio ini dijelaskan oleh Audrey, yang merupakan salah satu devisi dari stasiun radio ini yang diwawancari melalui via WhatsApp.

"Berdirinya itu tanggal 23 Maret 2007, jadi kemarin baru ulang tahun ke-14" (Wawancara dengan Audrey

Vania Zachrani Kinasih, Humas Ikom Radio UMY, 20 April 2021: 15.30)

Ikom Radio adalah radio komunitas yang di bawah naungan prodi ilmu komunikasi jadi segmentasi ikom radio lebih ke mahasiswa- mahasiswa fisipol. Radio komunitas dimiliki, dikelola, diperuntukkan, diinisiatifkan, dan didirikan oleh sebuah komunitas sehingga sering disebut sebagai radio sosial, radio pendidikan, atau radio alternatif. Dengan demikian, radio komunitas dapat dijadikan sebagai wahana komunikasi milik masyarakat yang potensial untuk melayani kepentingan komunitasnya sendiri. Dengan kata lain, fungsi dan potensi radio komunitas sangat stategis untuk memercepat perubahan sosial di kalangan masyarakat yang mendirikan dan mengelola radio komunitas (P. Rianto, Rahayu, 2014). Ikom Radio adalah radio komunitas yang di bawah naungan prodi ilmu komunikasi jadi segmentasi Ikom Radio lebih ke mahasiswa- mahasiswa fisipol. Ikom Radio juga mewadahi anak-anak komunikasi dan fisipol dengan program Watch On Campus, sesuai dengan wawancara' berikut:

"Kita juga ada program Watch On Campus nah itu tu untuk program ini khusus untuk memberi tau seputar informasi-infrormasi apa saja yang ada di kampus contohnya acara prodi dan lain-lainnya, dan untuk programnya pun menyesuaikan dengan selera atau kesukaan yang cocok dengan anak fisipol, seperti program musik, atau tips dan trick." (Wawancara dengan Ridho Awan Kusuma - Direktur Ikom Radio UMY, 13 April 2021: 13.45).

Dengan kondisi pandemi sekarang Ikom Radio masih tetap melakukan streaming walaupun sistemnya bukan lagi on air melainkan melalu tapping.

"Semenjak pandemi Ikom Radio itu masih melakukan streaming tapi sistemnya ga on air melainkan melalui tapping. Dampak dari pandemi ini juga menyulitkan ikom radio dalam hal berkoordinasi, untuk mengatasi hal 
ini ikom radio memanfaatkan platform zoom. Dan untuk melakukan siaran ikom radio membuat kebijakan kepada anggota agar mengelist anggota yang menyanggupi diri untuk melakukan siaran lewat tapping zoom. Ikom radio juga membuat kebijakan yang ketat kepada anggota yang tidak melakukan siaran yaitu dengan memberi teguran, memberi surat tindakan, bahkan sampai dikeluarkan." (Wawancara dengan Ridho Awan Kusuma - Direktur Ikom Radio UMY, 13 April 2021: 13.45).

Sebuah organisasi haruslah mempunyai suatu aturan yang membatasi semuanya untuk kebaikan kita bersama (organisasi), apalagi untuk sebuah media massa elektronik seperti radio ini diperlukan aturanaturan yang tegas dan detail agar semua crew mematuhinya. Setiap bidang pekerjaan pasti mempunyai hambatan atau kesulitan tersendiri yang harus dihadapi oleh orang yang berada pada bidang tersebut, banyak hambatan yang bisa kita alami dari bidang tersebut, baik hambatan internal maupun eksternal. Dengan adanya hambatan-hambatan yang kita alami dalam suatu pekerjaan, maka hambatan itu bisa berakibat baik dan buruk bagi kita ataupun perusahaan (Adi Muhammad Ramadhan, 2018).

Audrey pun menjelaskan bahwa struktur kepengurusan di Ikom Radio ternyata memiliki penambahan devisi, dikarenakan pandemi seperti sekarang ini Ikom Radio jadi lebih aktif di akun sosial media nya.

"Di Ikom Radio itu ada 6 devisi, awalnya si cuma 5 yang satu itu tambahan jadi ada BPH (Badan Pengurusan Harian), direktur, wakil, sekertaris 1, sekertaris 2, bendahara 1, bendahara 2, terus ada produksi, ada teknikal support, ada humas, program, nah terus tambahannya itu media kreatif. Di tambahin media kreatid sebenernya buat ngurus social medianya Ikom karena Ikom itu punya banyak social media kayak Twitter, Instagram, terus sekarang juga ada Tik Tok. Sebenernya dulu itu social media nya dipegang sama humas, cuma karna humas itu udah melakukan hubungan secara langsung dengan pihak luar jadi sosmednya itu agak ga keurus karna kan humas juga kerjaannya ga cuma sosmed tapi juga ngurus hubungan eksternal Ikom dan internalnya juga dan sosmed itu juga harus bikin konten jadi karena ga kepegang jadi bikin devisi media kreatif" (Wawancara dengan Audrey Vania Zachrani Kinasih, Humas Ikom Radio UMY, 20 April 2021: 15.30)

Untuk target pasaran streaming, Ikom Radio juga berfokus pada ranah Fisipol, kemudian ingin memperluas target pendengar mereka ke masyarakat luas, dikarenakan streaming ini dapat didengar oleh siapapun dan tidak hanya anak Fisipol saja. Tidak seperti dulu, dimana Ikom Radio hanya dapat didengarkan secara offline di lobby gedung Fisipol, kini siaran Ikom Radio dapat diakses melalui streaming. Oleh karena itu Ikom Radio jadi memperluas target pendengar mereka. Pengelola radio melakukan berbagai strategi guna menarik dan memertahankan minat pendengar, khususnya di kalangan generasi muda. Pengelola radio mengenalkan konvergensi media sebagai cara mengakses radio, seperti penggunaan teknik siaran streaming dan podcasting meskipun secara umum radio transistor masih merupakan pilihan utama publik pendengar radio. Namun, ada kecenderungan yang sangat kuat dimana khalayak terutama di kalangan anak muda yang telah beralih ke handpone sebagai sarana mendengarkan radio (Sataloff et al., n.d.).

"Target audiensnya si sebenernya ya kalau online di kampus target audiensnya ya mahasiswa tapi kalua pandemi/online kaya gini targetnya ya luas sih soalnya kan yang dengerin ga cuma mahasiswa" (Wawancara dengan Audrey Vania Zachrani Kinasih, Humas Ikom Radio UMY, 20 April 2021: 15.30)

Dari wawancara dapat ditemukan informasi bahwa pandemi Covid-19 berdampak langsung terhadap proses produksi siaran streaming Ikom Radio. Seperti yang biasanya on air sekarang melalui tapping, dan menyulitkan Ikom Radio dalam hal berkoordinasi. Dengan manajemen yang baik dan komunikasi yang dilakukan dari pihak internal Ikom Radio meminimalisir terjadinya miss komunikasi, sehingga semua proses produksi dapat terlaksana dengan lancar.

Dari laman instagram Ikom Radio sendiri, dapat kita lihat bahwa Ikom Radio ini terorganisasi dengan baik dan memiliki informasi media sosial yang rapi. Di bio instagram terdapat sebuah link yang memberikan semua informasi yang berkaitan dengan Ikom Radio. Di dalam link tersebut kita dapat 
dengan mudah menemukan semua hal terkait Ikom Radio, mulai dari Aplikasi Streaming, kemudian Website Streaming, kontak Whatsapp, Podcast, Twitter, dan juga TikTok. Tak hanya itu, Ikom Radio juga membuat ajang kompetisi khusus dalam bidang broadcasting untuk anak-anak SMA/Sederajat seluruh Indonesia. Ajang ini terdiri dari 5 kompetisi, yaitu Radio Announcer, News Anchor, Reporter, Jingle Radio, dan Presenter.

\section{PEMBAHASAN}

Di situasi pandemi seperti sekarang ini tidak mudah bagi semua orang, apalagi dikalangan para pekerja. Ada yang kehilangan pekerjaan mereka, kehilangan keuntungan mereka dan sebagainya. Hal ini sama seperti yang sedang dialami oleh Ikom Radio. Ikom Radio sangat kesusahan dengan adanya situasi Covid19 ini, terbukti dengan vakumnya organisasi ini diawal-awal pandemi Covid-19 masuk ke Indonesia. Saat ini, Ikom Radio melakukan siaran secara online atau dari rumah, karena mengikuti anjuran pemerintah untuk menerapkan aturan protokol kesehatan, salah satunya adalah Work From Home (WFH).

Di masa Covid-19 ini Ikom Radio mempunyai program streaming yang menjadi salah satu bukti inovasi di era disrupsi, ini merupakan sebuah layanan penyiaran audio yang ditransmisikan secara online melalui internet agar siaran radio bisa didengar di mana pun dan kapan pun mustamik inginkan. Hal ini tentunya berbeda dengan radio FM yang hanya dapat dijangkau dalam lingkup area tertentu. Ikom Radio sebagai radio komunitas di bawah naungan Prodi Ilmu Komunikasi Universitas Muhammadiyah Yogyakarta (UMY) turut berinovasi dengan menghadirkan layanan streaming radio. Kepala divisi Program Ikom Radio, Faturrohman mengungkapkan bahwa Streaming Ikom Radio menjadi salah satu program kerja utama Ikom Radio tahun ini.

Program Streaming ini sebagai bentuk untuk memenuhi keinginan Ikomers yang ingin mendengarkan siaran Ikom Radio tanpa harus stay di satu tempat. Mengingat sebelumnya, siaran Ikom Radio hanya bisa didengarkan di lobi Fisipol saja. Kenyataan lain bahwa pendengar radio di Indonesia saat ini mayoritas telah memiliki handphone yang sebagian memiliki fitur mendengarkan radio. Bahkan, mereka juga bisa koneksi ke internet. Oleh karena itu, Ikom Radio sekarang ini bisa diakses melalui handphone dengan cara meng akses website program siaran Ikom Radio Streaming yang diresmikan dan mulai dapat dinikmati pada 7 Juli.

Layanan radio streaming dapat diakses melalui website Ilmu Komunikasi atau aplikasi ikomradio khusus Android (dapat diunduh melalui link di bio Instagram resmi Ikom Radio @ikom_radio). Selain program siaran, Streaming Ikom Radio juga turut menyiarkan audio dari meeting atau webinar yang akan dipublikasikan oleh Prodi Ilmu Komunikasi, Universitas Muhammadiyah Yogyakarta. Melalui streaming ini, pendengar dapat bergabung dengan me-request lagu melalui chatbox yang tersedia pada website maupun aplikasinya. Untuk informasi streaming dan berbagai informasi Ikom Radio menarik lainnya, silakan dilihat pada instagram resmi Ikom Radio.

Adaptasi Ikom Radio dari analog menjadi digital di masa pandemi Covid-19 ini berjalan dengan baik. Dari yang hanya bisa didengarkan di gedung Fisipol saja sekarang bisa didengarkan dimana saja dan kapan saja melalui handphone kita masing-masing. Di era konvergensi media (penggabungan radio analog dan audio streaming), Ikom Radio memilih fokus pada radio internet (radio streaming online) dan konten podcast. Ikom Radio sekarang menjadi Badan Semi Otonom (BSO) dibawah naungan Himpunan Mahasiswa Jurusan (HMJ) Korps Mahasiswa Ilmu Komunikasi (KOMAKOM) Universitas Muhammadiyah Yogyakarta (UMY). 


\section{KESIMPULAN}

Akibat covid -19 yang sering disebut juga dengan virus corona, yang membuat semua aktivitas terhambat karena adanya virus corona ini, dan sudah menyebar di beberapa negara termasuk Indonesia. Sementara itu semua aktivitas dilakukan secara daring seperti pembelajaran ini sementara dilakukan secara daring dan termasuk juga penyiaran Ikom Radio yang dilakukan secara tapping. Ikom Radio didirikan sebagai pembelajaran penyiaran (Broadcast) dibawah naungan prodi Ilmu Komunikasi Universitas Muhammadiyah Yogyakarta. Ikom Radio memilih untuk fokus pada radio internet (radio streaming) dan membuat konten - konten podcast. Dengan kondisi saat ini masih pandemi Ikom Radio masih tetap melalukan siaran (streaming) walaupun sistemnya bukan lagi on air melainkan tapping. Dari dampak pandemi ini menyulitkan Ikom Radio untuk berkoordinasi, untuk mengatasi hal ini Ikom Radio membuat kebijakan untuk menfaatkan platfrom zoom.

Selain program siaran (streaming) Ikom Radio juga turut menyiarkan audio dari meeting atau webinar yang akan di publikasikan oleh prodi Ilmu Komunikasi Umiversitas Muhammadiyah Yogyakarta (UMY). Melalui streaming ini, pendengar dapat bergabung dengan me-request lagu melalui chatbox yang tersedia yg ada di website maupun aplikasinya. Terkait informasi mengenai streaming dan berbagai informasi tentang Ikom Radio menarik lainnya, bisa di lihat di akun Instragramnya Ikom Radio yaitu @ikom_radio selain mencari informasi diakun Instagram Ikom Radio, kalian juga bias update mengenai Ikom Radio itu sendiri.

\section{PERSANTUNAN}

Terima kasih kepada Dr. Fajar Junaedi yang telah membimbing proses riset jurnal ini yang berjudul "Adaptasi Ikom Radio : Dari Analog menjadi Digital di Masa Pandemi Covid-19" dalam mata kuliah Kajian Kritis Iklan di Program Studi Ilmu Komunikasi UMY, selama satu semester genap tahun akademik 2020/2021 yang menghasilkan output berupa artikel ini.

\section{REFERENSI}

Asri, R. (2020). Digitalisasi Penyiaran. 19.

Chantler, P., \& Stewart, P. (2009). Essential Radio Journalism.

Choirunnissa, S. (2021). Strategi komunikasi radio suara muslim surabaya dalam mengelola program siaran di tengah pandemi covid-19.

Damanik, H. J., Parlina, I., Tambunan, H. S., \& Irawan, E. (2017). Sistem Pendukung Keputusan Dalam Seleksi Penyiar Radio Boss Fm 102.8 Pematang Siantar Menggunakan Metode Electre. KOMIK (Konferensi Nasional Teknologi Informasi Dan Komputer), 1(1), 38-44. https://www.ejurnal.stmikbudidarma.ac.id/index.php/komik/article/view/470

Fadhal, S. (2005). Media, Komunikasi dan Informasi di Masa Pandemi Covid 19.

Giannini, V., Craninckx, A. B. (1377). Baseband Analog Circuits for Software Defined Radio.

Gultom, A. D. (2015). Kajian implementasi radio siaran digital di Indonesia (Study of digital radio broadcasting implementation in Indonesia). Buletin Pos Dan Telekomunikasi, 13(2), 133. https://doi.org/10.17933/bpostel.2015.130203

P. Rianto, Rahayu, I. Y. (2014). Kepemilikan dan Intervensi Siaran.

Pinasti, F. D. A. (2020). Analisis Dampak Pandemi Corona Virus Terhadap Tingkat Kesadaran Masyarakat dalam Penerapan Protokol Kesehatan. Wellness And Healthy Magazine, 2(2), 237-249. https://doi.org/10.30604/well.022.82000107

Putri, A. (2020). Implementasi Komunikasi Pemasaran Radio Suara Surabaya Dalam Mendapatkan Iklan Pada Masa Pandemi Covid-19. Jurnal Commercium, 3(2), 1-12. https://ejournal.unesa.ac.id/index.php/Commercium/article/view/36316

Ramadhan, A. (2018). Peranan Station Manager Dalam Mengembangkan Radio Komunitas Di Politeknik Lp3I Bandung. Komversal, 4(1), 13-27. https://doi.org/10.38204/komversal.v4i1.300 
Sataloff, R. T., Johns, M. M., \& Kost, K. M. (n.d.). KEPEMILIKAN DAN INTERVENSI SIARAN.

Sugiana, D., Setiaman, A. (2019). Komunikasi dalam Media Digital.

Widiyasari, A. A., Widagdo, M. B., Musyafi, \& Ayun, P. Q. (2015). Jurnal Ilmu Komunikasi AKRAB. Jurnal Ilmu Komunikasi, 251-266. 